\title{
BEING DEAF IN NEW ZEALAND
}

\author{
Peter Fogarty
}

\begin{abstract}
Many experiences of my life have defined who I am today. This paper reflects on a defining quality of my experiences - being Deaf in New Zealand.
\end{abstract}

\section{INTRODUCTION}

Silence descended upon me when I endured pneumococcal meningitis and thereafter lived with deafness. The nature of memory is non-linear; it is a quantum space with synapses interconnecting information. My memories of being Deaf are fragmented, because the things that define being Deaf are not continuous. I have not expressed every event of being Deaf in my life, such as publishing Moving Hands, and going to Deaf clubs, but instead I present a montage of moments to show a pattern in the weaving together of fragments in silence.

\section{THE BEGINNING}

I was too young to remember the illness that took my hearing. We don't know where I picked up the meningitis bacteria. Vectors for infection included a visit to a sick relative, playing on a cousin's horse-training farm, and from any of my companions. The meningitis bacteria is communicated by contact with people and most people carry the pneumococcal bacteria so I could have got it from my friends, and picking up pneumococcal meningitis from farm animals in the spring is not unusual. It is a mystery I will never be able to understand.

I was taken to a weekend doctor when I took ill on Saturday morning. His diagnosis was inconclusive. Nan, my mother rang him later in the night when my condition had deteriorated. He told Nan to 'give him more Panadol, he wont die overnight, you know'. My own general practitioner misdiagnosed 
my illness and a hour after his visit I went into convulsions. I went to hospital and was in a coma for about fifteen hours. Nan thought I was deaf before I left the hospital and mentioned it to the pediatrician. He said it was a withdrawal as a result of the trauma of hospitalisation.

I had no other ill effects from pneumococcal meningitis and the following week Nan confirmed that I had become deaf when I showed no reaction when she called my name or clapped behind me. Nan described me sitting on the floor playing with my toys, but when she called, 'Peter?' I did not turn to face her or make any indication that I had heard her. Nan came up behind me and clapped loudly. Nothing happened and she realised something was wrong. I could not hear. I went back to hospital two weeks later for a checkup and the pediatrician said to my mother, 'Of course he is deaf, he had meningitis after all'.

\section{PLUGGING IN}

I can't remember being able to hear without technology. My childhood memories are clear, but disconnected from sound. I remember things that happened, but not how they sounded. Through the crack of the slightly ajar door I see my mother walk down the hallway to me in silence. Sound was a compromise; a part of me that I had to strap on every day. At primary school my hearing aid was strapped to my chest in a crossover harness. I got ear-level hearing aids a year or two later. Wendy Lamb, my teacher, had a large radio microphone on a cord around her neck. This struck us on the head when she bent over to look at our school work. When I went to play at the mixed kindergarten of deaf and hearing children at Rutland Street I could tell who was like me because we had the same hearing aids strapped to our chests.

\section{STILL FEELING}

I still have bone conduction hearing. This is what I hear: the keys clicking as I type; my partner closing the door heavily downstairs when she comes home; the wind knocking the door to the deck against the wall; a heavy vehicle passing by. I feel their sounds in my bones. The keys clicking feel perhaps much like they sound when I plug in my cochlear implant; annoying and much like the sound I always imagined the word 'clack' describes. The reverberating thud of the front door closing below me is a solid bang with quivering aftershocks as ripples move up through the frame of the house to my office above the door. The wind bangs the window, the door, and sometimes slams one of the bedroom doors beneath me; I often go downstairs to see who has come because it feels like a visitor has arrived. 
Visits to hearing adults supporting the Deaf world were a regular part of my life when I was growing up. I had a lot of extra tutoring throughout my childhood with visits from itinerant teachers of the Deaf three times a week during primary school. I also visited the audiologist a few times a year to have my hearing aids calibrated after a hearing test and new ear moulds made to correct the whistling from out-grown ear moulds. I tried to count the number of holes in the sound-proofing tiles on the walls. I played with plastic toys and jig saw puzzles and endured all the different tests. I liked the feeling of the ear mould putty as it was injected into my ears. The cool solidity felt like I was being filled up completely, and I was always sad when it had hardened and had been removed. The reverse was true for wearing hearing aids. Sound was and is a thing to be endured, a pressure that never stops pressing. I am immersed in distorted sound for as long as I wear a hearing aid. My cochlear implant has improved upon the clarity of sound; it is a sound free from amplified distortion, but still not quite there, I almost prefer the old sound; its like the difference between vinyl and CD music. A warmth disappears into the spectrum not transmitted by the cochlear implant.

\section{IN THE MAINSTREAM}

I was mainstreamed at St. Martin's Primary School in Christchurch. I was the only Deaf there until another boy came for a year or two. Itinerant teachers from Sumner School for the Deaf visited at least three times a week. Sometimes they came for a hour every day. It changed a bit from year to year, but it was never less than three times a week in the beginning. I was very well supported. In my first year of primary school I had extra one-on-one reading classes with my teacher, Mrs White, in a small resource room filled with School Journal boxes and other educational material. In later years, I came here to work with my itinerant teachers. I went to speech therapy lessons one morning a week until I was fifteen at Sydenham Primary. Recently the school burnt down and now the site is a vacant lot.

I remember many things about primary school, but very few of them were related to my being Deaf. Apart from having to wear technology, meeting my itinerant teacher while everyone else did music class, my life was much like everyone else's: climbing trees, playing spontaneous games of bull rush or gohome-stay-home on the school fields, competitive rounds of paddle tennis and all the things that kids do. 
I went on a few Keep In Touch (КIт) Deaf camps up in Hamner Springs during autumn school holidays with my parents and other parents with their Deaf children who were mainstreamed or at Sumner School for the Deaf. We were oral and sign Deaf. I don't remember using a lot of sign language. Between the oral Deaf, we didn't know much sign language. Sure, we could all do the alphabet, and say a few other words like 'hello, you', 'be cool until after school', and other basic signed English like 'I am good', 'You are bad', among other things. But by no means were we fluent. Nan went to evening sign language classes at Sumner School for the Deaf for two years when I was at preschool and taught me all the signs she knew before I started school. I wasn't very interested in learning sign language, but I had a keyword vocabulary in sign and Nan used to correct my English by using conjunction signs like 'is', 'are', and the alphabet. Most parents of mainstreamed Deaf gave their children some sign language through Total Communication. I vaguely knew other Deaf from the school for the Deaf in Sumner and I knew that they were being taught with sign language as well as the oral method. Nan tells me that she thought I wasn't very interested in sign as I was reliant on lip-reading, and resisted sign language because it made me too conspicuously Deaf.

\section{LINWOOD HIGH SCHOOL}

It was at Linwood High School (now Linwood College) that I learnt to read Total Communication. Because Total Communication is more or less signed English, I was able to guess ahead of the words I speech-read and watch for the corresponding hand shapes. I could read signs, but because I had not been taught signs, and my interactions with other Deaf were limited to the Deaf Unit, playground encounters, and in assembly where we would sit together to watch our teacher of the Deaf interpreting for us. I still did not learn to sign. I formed a prejudice: I felt sign language was inferior to English and was of no use to me. I could function far better and more independently with my speech-reading with strangers. I could not imagine trying to communicate with people solely by sign language. I had to be able to speak to anyone without being dependent on someone else to interpret on my behalf.

When I entered third form at Linwood High, I was placed in a low stream with the other Deaf children. Nan queried this as she had seen my entrance exam marks. She discovered that I had scored in the 80 percentile, high enough to be placed in one of the top streams. Sumner School for the Deaf was not confident that I could manage English or Social Studies. They said that I had 
scored higher than any of the other Deaf who had ever enrolled at Linwood High School. Nan went to Sumner School for the Deaf and asked if I could be put at my grade level and do all subjects. I was moved up several streams to the B stream. I silenced the skeptics coming second in my class that year. The following year, 1988, I came first in my class. I was promoted to the top stream in fifth form and I found the measure of my peers, achieving in the middle of the class, but earning a general excellence in English as one of the top four English students. The pattern repeated the following year with another general excellence in English, and in seventh form, in recognition of my overall efforts, I was awarded a prize for special endeavour that was created to honour my high school work. I stood up on the stage and watched the emotions on the faces of the school and wondered what the prize giver was saying. A list of things I had done had been read out: I'd won a speech competition in fourth form, competed in waterpolo in the national schools competition several years in a row, excelled academically, popular socially, etc.

My experience of being Deaf at high school was marked by the presence of teachers of the Deaf taking notes for me in each class. I do not remember being taught by my teachers of the Deaf, but I do remember having little 'What does that mean?' conversations during the course of each class. They gave me lots of extra work-sheets to do for homework, especially in math and science, to ensure I missed nothing. Because I shared few classes with my Deaf peers, I have little idea how my Deaf peers coped with the same trials as I did: speechreading the teacher, reading the notes and copying down blackboard lessons, and socialising with my hearing peers.

I played waterpolo and was active in sports, racing a two-person Sunburst yacht, riding my bike the five kilometers to school, taking the school bus, going on camps, working in the woodwork room, and reading. I skateboarded as a hobby. Most of my friends went to Hagley High School, and I mixed entirely in the hearing world. For all purposes, I had assimilated entirely into the hearing community and my peers would forget that I couldn't hear, and often say so.

\section{NEW YORK, NEW YORK}

I went to school at Lexington School for the Deaf in Queens at the end of sixth form in December 1991. We had privately hosted Darren, a student from Lexington for several weeks earlier. We had showed him around the South Island and he attended classes with me and with Pollyanna Ferguson at van Asch College. He also stayed with the Ferguson family for a few weeks. Darren 
is a very nice man with whom I have lost contact. He had a great time in New Zealand, but grew homesick near the end. The oral culture of my family and the large size of my home in comparison with the condominium apartment he lived in with his brother and mother was probably a strain on his comfort zone.

I went to stay with Darren's family in their condominium next to a large mall in Staten Island for nine weeks. Every morning Darren and I took a bus over the Verrazano Narrows bridge to Brooklyn and along the river to Lexington School for the Deaf in Queens. It was the first time that I was living entirely within a Deaf culture based on sign language. I did not have the opportunity to become fluent in ASL (American Sign Language), but I picked up the rudiments of communication. Then, as now, the problem is not understanding what a person means, but in recognising details. I know she is talking about having dinner in the city, but when?!

The American education curriculum was approximately one year behind New Zealand, so I found the material taught in class very easy and did not do much original schoolwork. Once I taught the Science teacher a new way of remembering formulas based on the pyramid shape, and she was excited that there was a very easy way of remembering three-part formulas.

I remember the metal detectors at the front doors, the way everyone sat down to breakfast at school, students signing in the hallways, and watching dawn sunlight glinting off wintry Manhattan as we crossed the Verrazano Narrows bridge and drove along the Brooklyn expressway.

\section{VISITING GALLUDENT}

We drove down from New York City to Washington to visit Galludent University. The wide ten lane motorways meant that our convoy of three cars could comfortably drive in parallel all the way through New Jersey, and we could all sign to one another all the way down to Washington, DC. The drive down was exhausting but we were shown around the main memorial sites in the car, the Vietnam memorial, the square with the Lincoln memorial and the obelisk. I visited the dorms at Galludent and we caught up with some of Darren's friends. Much of the time is a blur because we were all drinking a lot. I remember that some guys bought a quart of vodka and proceeded to make it stronger by boiling it. 
IN THE DEAF WORLD

I have conflicting feelings about the Deaf world. I know I am of the Deaf world, but it does not form a substantial part of my life. My dips into the Deaf world began at the Rutland kindergarten. Mrs Lofts was my teacher. It was a deaf and hearing Kindergarten with a Deaf Unit attached. The memories of that time are largely visual and I remember the shapes of the buildings and there are vague impressions of being on a tricycle, the diamond shape of a shed or outhouse, and the sandpit. I learned to sign the alphabet, I think, at this time.

People like Paul Buzzard came to visit my parents as part of their introduction into the Deaf world. I don't remember much of those visits. Paul Buzzard recently told me that I was a very alert child, very clearly a Deaf child, and he was saddened by my parents' desire that I receive an oral education as he has always advocated Deaf be taught in sign language. My signing Deaf peers were mostly the Ferguson family, particularly Pollyanna, then Joyce, and then Oliver when he enrolled at Linwood High School.

I was a flag bearer at the World Deaf Games in Christchurch in 1989. I was exposed to a wide range of Deaf from all over the world, watched them excel at their sports and communicate with one another in all kinds of sign language, and their communications were rapid and bewildering. The slowness of TC was gone! My father, John Fogarty, was the lawyer for the New Zealand Deaf sports organization at that time. He was their lawyer for around seventeen years and I am always meeting elder Deaf who say that my father is a good man.

\section{MY SIGN NAME}

I was given my sign name on the American road trip. My old sign name was worm because I am a constant reader. In New Zealand, people are given signs for a defining characteristic of who they are. In America, people are given sign names based on the initial for their first name, and perhaps also a character of their personality. I was given the sign name of $\mathrm{P}$ held under the chin, with the forefinger scissoring as if I am talking. I was given this name because so often the lot fell to me to be the oral communicator for the group because I had the best spoken English skills of everyone in the group. My New Zealand accent didn't appear to be a problem. While I was actually seventeen, I looked over twenty-five with my long hair and so I was able to buy food, tickets and alcohol without photo ID or being questioned. I used my voice all the time to 
facilitate things for my Deaf friends. The new sign name wasn't actually much of a stretch, as the standard sign name for Peter is very similar, in the same place, but closer to the sign for bird.

1ST NATIONAL DEAF CAMP: CAMBRIDGE 2005.

I was a team leader on the first national Deaf youth camp organized by the DEAFinitely Youth Group. It was my first full immersion in the Deaf community since New York. I'd been to captioned movie premieres and attended NZsL classes at Auckland University of Technology, and visited the Deaf clubs in Christchurch and Auckland but they were always just an evening out. There were twelve of us in the leadership group. I had met most before, but I didn't really know them and met a few more new people as well. It was an international gathering of Deaf. Two American women were there, one as a co-organiser and another as a drama workshop presenter. There were two Brits too, an English organizer and a Scots leader. I had met most of the other team leaders before, but Philip King was the only one I had spent the most amount of time with as he had been at Linwood High School at the same time as I was. We were in charge of forty-five Deaf kids from all over New Zealand. I was invited to the first National Camp for the Deaf because of the NZDeaf email list and it turned out that one of the boys in my team also subscribed to the list. I struggled with my NZsL during the camp, but everyone was happy that I was trying to express myself with sign language. There were two hard of hearing Deaf in my group, which meant that half the time we needed an interpreter with our group to translate both ways!

\section{LITTLE THINGS ABOUT BEING DEAF}

Being Deaf is to live in a world of silence. People who cannot experience silence seek to bring their world of sound into being. I have a cochlear implant that gives dimension to the movement of life; for all living things move, and as they move, they transmit information. But it is not necessary. Sound is not needed to comprehend information with senses that can be strengthened by lack. Intuitions are reinforced by the need to speechread and absorb nonverbal, non-manual signifiers. Sensitivity is developed and personal space becomes a visual space. Silence in the field of vision is a field where nothing moves, nothing intrudes, and all is still. The uninterrupted gaze finds peace in the gentle susurrous of motion in the ripples of the sea, the castles of the air, and mountains' timeless thrust. Silence forms the fabric of my reality. I endure other people's desire to bring sound into my life. This is being Deaf. 